\title{
O uso de Is 52,13-53,12 em Rm 5,12-21: Uma análise a partir do Método exegético- interpretativo de G. K. Beale
}

Orientadora: Maria de Lourdes Corrêa Lima

Doutorando: Samuel Brandão de Oliveira

Área de Concentração: Teologia Bíblica

Linha de Pesquisa: Análise e Interpretação de Textos do Antigo e Novo Testamento

Projeto de Pesquisa: Exegese Bíblica: princípios de interpretação e metodologia

O uso do texto de Rm 5,12-21 quase exclusivamente nos debates a respeito da ori-gem e da universalidade do pecado levou a uma supervalorização da discussão a respeito do segmento $12 \mathrm{~d}$, passando quase desapercebidos aspectos fundamentais para a compreensão da mensagem teológica contida no texto paulino. Um desses aspectos transcurados foram as alusões a Is 53,1112. A presente pesquisa pretende ser uma contribuição para que se possa perceber os efeitos produzidos por essas alusões nos contemporâneos de Paulo, as quais trazem à mente dos ouvintes/leitores a figura do Servo que por seu conhecimento justifica os muitos presentes no texto isaiano, como também as categorias bíblico-teológicas do Novo Exxodo e da Nova Criação contidas no seu contexto e com as quais está profundamente interligado. A partir disso, a recuperação do valor dessas alusões possibilitaria uma compreensão mais adequada do potencial hermenêutico, teológico e retórico da perícope, o que resultaria em uma verdadeira contribuição para o debate teológico tendo-se em vista o espaço que a perícope paulina ocupa em tal debate. A metodologia a ser utilizada será aquela proposta por G. K. Beale, a qual, contemplando os aspectos sincrônicos e diacrônicos da pesquisa, propõe uma análise exegético-interpretativa, mostrando-se assim muito adequada para que se possa perceber a intenção de Paulo ao utilizar o texto isaiano.

Palavras-chave: Servo sofredor. Adão. Graça. 